\section{Editorial}

Check for updates

\title{
Clinical and Laboratory Predictors of Egg Allergy Resolution in Children
}

\section{OPEN ACCESS}

Received: Apr 25, 2019

Accepted: Apr 26, 2019

\section{Correspondence to}

Jeong Hee Kim, MD, PhD

Department of Pediatrics, Inha University

Hospital, College of Medicine, Inha University,

27 Inhang-ro, Jung-gu, Incheon 22332, Korea.

Tel: +82-32-890-2843

Fax: +82-32-890-2844

E-mail: kimjhmd@inha.ac.kr

Copyright (c) 2019 The Korean Academy of Asthma, Allergy and Clinical Immunology . The Korean Academy of Pediatric Allergy and Respiratory Disease

This is an Open Access article distributed under the terms of the Creative Commons Attribution Non-Commercial License (https:// creativecommons.org/licenses/by-nc/4.0/) which permits unrestricted non-commercial use, distribution, and reproduction in any medium, provided the original work is properly cited.

ORCID iDs

Jeong Hee Kim (iD)

https://orcid.org/0000-0002-7054-8552

Disclosure

There are no financial or other issues that might lead to conflict of interest.

\section{Jeong Hee Kim (1D *}

Department of Pediatrics, Inha University Hospital, College of Medicine, Inha University, Incheon, Korea

- See the article "Reduction Rate of Specific IgE Level as a Predictor of Persistent Egg Allergy in Children” in volume 11 on page 498.

The prevalence of immunoglobulin $\mathrm{E}$ (IgE)-mediated egg allergy is one of the most common food allergies in infants and young children; the estimating rate is about $0.1 \%$ to $8.9 \%$, with the lowest rate in Greece $(0.07 \%)$ and the highest rate in the population-based Health Nuts study $(8.9 \%) .^{1-4}$ The prevalence of egg allergy in infants is $2.8 \%$ in Korea. ${ }^{5}$

According to a study of meta-analysis, egg allergy is the second most common food allergy (FA) in children and adults. ${ }^{1}$ Egg allergy is the second most common immediate-type FA (cow's milk, 37\%; egg, 34\%) in Korean children less than 2 years of age. ${ }^{6}$ Egg allergy can cause life-threatening anaphylactic reactions that lead to significant morbidity and impaired quality of life, and also can develop other allergic diseases, such as atopic dermatitis and/or asthma, simultaneously or later in life.

Hen's egg contains high-quality proteins and nutrients, and is widely consumed worldwide in various ways. Thus, the patients with egg allergy can hardly avoid eating foods that are containing eggs, so that allergic reactions from accidental consumption are common. Among the cases with food-induced anaphylaxis, the egg is the second most common cause, followed by cow's milk in Korean young children. ${ }^{6} \mathrm{~A}$ nationwide multi-institutional survey in the US reported that hen's eggs, fruit, peanuts and tree nuts are frequently observed in anaphylactic cases of children under 5 years of age. ${ }^{7}$ Hen's egg and cow's milk are the most frequent causes of anaphylaxis among children under 3 years of age in a European study. ${ }^{8}$

It is difficult to know the exact natural course of specific FA, since various factors, including food culture, are involved therein. Nevertheless, it is important to evaluate and predict the natural course of specific FA for assisting in the personalized care of individual patients. Prognostic factors should also be investigated to understand the natural course of FA.

Fortunately, egg allergy is expected to resolve in the majority of children by school age. ${ }^{9}$ However, some studies on the natural history of egg allergy have reported different findings in terms of the average age at which allergy resolves. The population-based cohort HealthNuts study followed up infants who had a detectable wheal to egg allergen and positive oral egg challenges, and reported that $47 \%$ of infants with egg allergy developed tolerance by the age of 2 years. ${ }^{10} \mathrm{~A}$ retrospective study using chart review of children with egg allergy 
(median age at initial visit, 14 months; median initial egg specific IgE [sIgE], $7.3 \mathrm{kU} / \mathrm{L}$; and the median peak egg sIgE, $9.4 \mathrm{kU} / \mathrm{L}$ ) in a tertiary referral center reported that only $11 \%$ of children developed tolerance by the age of 4 years, $26 \%$ by the age of 6 years, and $82 \%$ by the age of 16 years when tolerance was defined as tolerating concentrated egg or having a last recorded egg sIgE level of less than $2 \mathrm{kUA} / \mathrm{L}$ and no history of clinical reactivity in the previous 12 months. ${ }^{11} \mathrm{~A}$ cohort in the Consortium of Food Allergy Research followed up children aged from 3 to 15 months with clinical egg allergy and found that about half of children with egg allergy resolved at a median age of 6 years when tolerance was defined as tolerating concentrated egg products. ${ }^{12}$

In the current issue of the $A A I R, \operatorname{Kim}$ et al..$^{13}$ reported that about $82 \%$ of children with egg allergy (mean age at diagnosis, 14 months) resolved at a median age of 3 years. Of infants with egg allergy in another study in Korea, 90\% without atopic dermatitis developed tolerance at the age of 3 years, while $60 \%$ with atopic dermatitis. ${ }^{14}$ Tolerance developed in $30 \%$ of children with egg allergy by the age of 3 years, $59 \%$ by the age of 5 years, and $73 \%$ by the age of 6 years in Japan. ${ }^{15}$ In previous studies, there are big differences in the natural course of egg allergy, which may be attributed to differences in study subjects and methods as well as cultural differences in the way foods are consumed.

Although inconsistent findings for predicting egg allergy resolution have been reported, indicators known to be related with developing tolerance or persisting allergy are severity of clinical reaction, skin prick test (SPT) reactivity, age at diagnosis, comorbid atopic dermatitis, serum sIgE levels, and rate of change in SIgE levels or SPT reactivity. ${ }^{16}$ In addition, component-resolved diagnoses and laboratory-based cellular assays ${ }^{17,18}$ have been investigated to predict the natural course of egg allergy. Among them, careful history taking for clinical characteristics and blood tests for sIgE to egg and component protein are readily available. Characteristics of initially presenting reactions, which only manifest skin symptoms, are associated with resolution..$^{12}$ Infants who were tolerant to baked egg were more likely to develop tolerance to regular egg compared to those allergic to baked egg ( $56 \%$ vs. $13 \%$ by the age of 2 years); however, the consumption of baked egg was more effective in developing tolerance compared to the initial baked egg reactivity. ${ }^{19}$ The baseline egg sIgE level has been considered a predictor of tolerance development. Many studies showed a favorable response in children with low sIgE levels, ${ }^{4,9,12,19}$ although some reported no association between sIgE level and prognosis. ${ }^{20,21}$

Kim $e t a l .^{13}$ in the current issue also attempted to identify the clinical factors predicting tolerance in children with IgE-mediated egg allergy. The authors showed that comorbidities (wheat allergy, peanut allergy and atopic dermatitis) and the egg sIgE level of $\geq 16 \mathrm{kU} / \mathrm{L}$ at diagnosis were less likely to resolve egg allergy. In addition, they reported that about $50 \%$ of children with peak egg sIgE level of $\geq 50 \mathrm{kU} / \mathrm{L}$ resolved, a higher remission rate than $11 \%$ of those who developed tolerance by the age of 4 years in a patient-based study of a tertiary referral center. ${ }^{11}$ In this current retrospective study, 226 out of 430 children with egg allergy were excluded because they could not be confirmed whether they developed tolerance at the last visit based on medical records, which may overestimate the resolution rate of egg allergy. ${ }^{13}$ Although this inconsistency of resolution rate in children with the same sIgE value between the 2 studies may be due in part to discrepancies in the study designs and methods including characteristics of study subjects, there may be more important reasons, which need to be clarified by well-designed prospective studies. They proposed a $30 \%$ change in egg sIgE level during a period of 12 months as a useful indicator of tolerance acquisition with 
area under the curve $0.835 .{ }^{13}$ This findings with decrease in egg sIgE levels are consistent with those of a study in which a $50 \%$ decrease in egg sIgE level over a period of 12 months resulted in a negative probability of $52 \%$ in the next challenge test ${ }^{22}$ and a Danish study which showed the association between tolerance development and decreases in IgE levels to the egg white and ovomucoid. ${ }^{21}$

In conclusion, the majority of young children with egg allergy develop tolerance over time, so that repeated egg challenge tests are required to determine the tolerance acquisition. The scheduling a challenge test should not be too early or too late to avoid unnecessary testing or unjustified restriction diet, which may impair growth and development. Integration of careful history of clinical characteristics and serologic markers can provide insights into the natural history as well as information for planning an appropriate time to perform the tests (blood and/or challenge).

\section{REFERENCES}

1. Rona RJ, Keil T, Summers C, Gislason D, Zuidmeer L, Sodergren E, et al. The prevalence of food allergy: a meta-analysis. J Allergy Clin Immunol 2007;120:638-46. PUBMED | CROSSREF

2. Osborne NJ, Koplin JJ, Martin PE, Gurrin LC, Lowe AJ, Matheson MC, et al. Prevalence of challengeproven IgE-mediated food allergy using population-based sampling and predetermined challenge criteria in infants. J Allergy Clin Immunol 2011;127:668-676.e1. PUBMED | CROSSREF

3. Peters RL, Koplin JJ, Gurrin LC, Dharmage SC, Wake M, Ponsonby AL, et al. The prevalence of food allergy and other allergic diseases in early childhood in a population-based study: HealthNuts age 4-year follow-up. J Allergy Clin Immunol 2017;140:145-153.e8. PUBMED | CROSSREF

4. Xepapadaki P, Fiocchi A, Grabenhenrich L, Roberts G, Grimshaw KE, Fiandor A, et al. Incidence and natural history of hen's egg allergy in the first 2 years of life-the EuroPrevall birth cohort study. Allergy 2016;71:350-7. PUBMED | CROSSREF

5. Lee AJ, Thalayasingam M, Lee BW. Food allergy in Asia: how does it compare? Asia Pac Allergy 2013;3:3-14. PUBMED | CROSSREF

6. Jeong K, Kim J, Ahn K, Lee SY, Min TK, Pyun BY, et al. Age-based causes and clinical characteristics of immediate-type food allergy in Korean children. Allergy Asthma Immunol Res 2017;9:423-30. PUBMED | CROSSREF

7. Ross MP, Ferguson M, Street D, Klontz K, Schroeder T, Luccioli S. Analysis of food-allergic and anaphylactic events in the National Electronic Injury Surveillance System. J Allergy Clin Immunol 2008;121:166-71. PUBMED | CROSSREF

8. Vetander M, Helander D, Flodström C, Östblom E, Alfvén T, Ly DH, et al. Anaphylaxis and reactions to foods in children--a population-based case study of emergency department visits. Clin Exp Allergy 2012;42:568-77. PUBMED | CROSSREF

9. Boyano-Martínez T, García-Ara C, Díaz-Pena JM, Martín-Esteban M. Prediction of tolerance on the basis of quantification of egg white-specific IgE antibodies in children with egg allergy. J Allergy Clin Immunol 2002;110:304-9.

PUBMED | CROSSREF

10. Peters RL, Dharmage SC, Gurrin LC, Koplin JJ, Ponsonby AL, Lowe AJ, et al. The natural history and clinical predictors of egg allergy in the first 2 years of life: a prospective, population-based cohort study. J Allergy Clin Immunol 2014;133:485-91. PUBMED | CROSSREF

11. Savage JH, Matsui EC, Skripak JM, Wood RA. The natural history of egg allergy. J Allergy Clin Immunol 2007;120:1413-7.

PUBMED | CROSSREF 
12. Sicherer SH, Wood RA, Vickery BP, Jones SM, Liu AH, Fleischer DM, et al. The natural history of egg allergy in an observational cohort. J Allergy Clin Immunol 2014;133:492-9. PUBMED | CROSSREF

13. Kim JD, Kim SY, Kwak EJ, Sol IS, Kim MJ, Kim YH, et al. Reduction rate of specific IgE level as a predictor of persistent egg allergy in children. Allergy Asthma Immunol Res 2019;11:498-507. CROSSREF

14. Park JS, Moon SJ, Lim DH, Jang HJ, Hwang SY, Park YS, et al. Effect of atopic dermatitis on the natural course of food allergy in infants and young children. Allergy Asthma Respir Dis 2017;5:256-61. CROSSREF

15. Ohtani K, Sato S, Syukuya A, Asaumi T, Ogura K, Koike Y, et al. Natural history of immediate-type hen's egg allergy in Japanese children. Allergol Int 2016;65:153-7. PUBMED | CROSSREF

16. Savage J, Johns CB. Food allergy: epidemiology and natural history. Immunol Allergy Clin North Am 2015;35:45-59.

PUBMED | CROSSREF

17. Berin MC, Grishin A, Masilamani M, Leung DY, Sicherer SH, Jones SM, et al. Egg-specific IgE and basophil activation but not egg-specific T-cell counts correlate with phenotypes of clinical egg allergy. J Allergy Clin Immunol 2018;142:149-158.e8. PUBMED | CROSSREF

18. Neeland MR, Koplin JJ, Dang TD, Dharmage SC, Tang ML, Prescott SL, et al. Early life innate immune signatures of persistent food allergy. J Allergy Clin Immunol 2018;142:857-864.e3. PUBMED | CROSSREF

19. Leonard SA, Sampson HA, Sicherer SH, Noone S, Moshier EL, Godbold J, et al. Dietary baked egg accelerates resolution of egg allergy in children. J Allergy Clin Immunol 2012;130:473-480.e1. PUBMED | CROSSREF

20. Eggleston PA. Prospective studies in the natural history of food allergy. Ann Allergy 1987;59:179-82. PUBMED

21. Gradman J, Mortz CG, Eller E, Bindslev-Jensen C. Relationship between specific IgE to egg components and natural history of egg allergy in Danish children. Pediatr Allergy Immunol 2016;27:825-30. PUBMED | CROSSREF

22. Shek LP, Soderstrom L, Ahlstedt S, Beyer K, Sampson HA. Determination of food specific IgE levels over time can predict the development of tolerance in cow's milk and hen's egg allergy. J Allergy Clin Immunol 2004;114:387-91.

PUBMED | CROSSREF 